Solid Earth Discuss., doi:10.5194/se-2016-4, 2016

Manuscript under review for journal Solid Earth

Published: 18 January 2016

(c) Author(s) 2016. CC-BY 3.0 License.

\title{
Pull-apart basin tectonic model is structurally impossible for Kashmir basin, NW Himalaya
}

\section{A. A. Shah}

5 Physical \& Geological Sciences, Faculty of Science Universiti Brunei Darussalam, Brueni

Correspondence to: A. A. Shah (afroz.shah@gmail.com)

\begin{abstract}
Kashmir Basin in NW Himalaya is considered a Neogene-Quatermary piggyback basin that was formed as result of the continent-continent collision of Indian and Eurasian plates. This model however is recently challenged by a pull-apart basin model, which argues that a major dextral strike-slip fault through Kashmir basin is responsible for its formation. And here it is demonstrated that the new tectonic model is structurally problematic, and conflicts with the geomorphology, geology, and tectonic setting of Kashmir basin. It also conflicts, and contradicts with the various structural features associated with a typical dextral strike-slip fault system where it shows that such a major structure cannot pass through the middle of the basin. It is demonstrated that such a structure is structurally, and kinematically impossible, and could not exist.
\end{abstract}

\section{Introduction}

Kashmir basin of NW Himalaya is a typical example of a piggyback basin that was forced as a result of the continent-continent collision of Indian and Eurasian plates (Burbank and Johnson, 1982). This tectonic model has been recently challenged by Alam et al. (2015, 2016). They have introduced a pull-apart basin model to argue that Kashmir basin was formed as a result of a large dextral-strike-slip fault that runs through it. This model however is structurally impossible (Shah, 2015b), and the present work further shows why Kashmir basin is not a pull-apart basin, and demonstrates that such a setting is inconsistent with the geology, topographic, geomorphology, and structural architecture of the basin. It however supports the classical piggyback basin model for its formation (Burbank and Johnson, 1983), and demonstrates that active movement on the NE dipping Kashmir basin fault (KBF) has greatly influenced the geomorphology of the basin.

\section{Tectonic Background}

Kashmir Basin is located on the NW portion of the active continent-continent collision ofIndian and Eurasian plates (Burbank and Johnson, 1982). The oval shaped basin filled with young sediments is considered a classical example of the piggyback basin of Neogene-Quatermary intermontane basins of the Himalayas (Burbank and Johnson, 1982). The bedrock geology suggests that the Upper Carboniferous-Permian Panjal Volcanic Series and Triassic limestone are the foundation rocks on which the Plio-Pleistocene fluvio-glacial sediments are deposited (Farooqi and Desai 1974). These sediments constitute a 
Solid Earth Discuss., doi:10.5194/se-2016-4, 2016

Manuscript under review for journal Solid Earth

Published: 18 January 2016

(c) Author(s) 2016. CC-BY 3.0 License.

1,300-m thick sequence of unconsolidated clays, sands, and conglomerates with lignite beds unconformably lying on the bedrock with a cover of recent river alluvium (Bhatt, 1976; Burbank and Johnson 1982; Singh 1982). This whole sequence is cut by a number of active thrust faults (Shah, 2013a, 2013b, 2015a; Ahmad et al., 2013; Shabir and Bhat, 2012), which are scattered through the oval shaped Kashmir basin (KB) that has a strike length of $\sim 150 \mathrm{~km}$ and is $\sim 50 \mathrm{~km}$ across (Fig. 1). The

5 recent deformation, along these faults, has modified the regional topography, which suggests that the regions on the NE of the Kashmir Basin are subsided, while those on the SW are uplifted (Shah, 2013a). The geomorphic expression of the active thrust fault trace is visible for a distance of $\sim 120 \mathrm{~km}$ (Shah, 2013a), wherein it cuts through $\sim 50,000-100,000$ year old sediments (e.g. Jaiswal et al., 2009), however, these dates do not show the dated sample locations on a map, which makes it harder to correlate these numbers with the faulting events.

\section{Pull-apart basin model impossible for Kashmir basin}

\subsection{Structural evidence}

The strike-length of Kashmir basin is $\sim 150 \mathrm{~km}$, and the mapped length of dextral strike-slip fault is $\sim 165 \mathrm{~km}$, and it runs though the center of the basin, which is structurally impossible (Fig. 2). If a major strike-slip fault has produced a pull-apart basin then the trace of that fault ought not to run in the middle of the basin. And to form $\sim 165 \mathrm{~km}$ long basin a series of $\sim \mathrm{SW}$,

15 and $\sim$ NE dipping normal faults are required (Fig. 2d). No evidence of such structures are preserved in Kashmir basin. This will also have a unique skeleton that could be related to topography, and geomorphology observed in an area with oppositely dipping normal faults, and that is not seen anywhere in Kashmir basin.

Further, the strike-length of the major dextral-strike slip fault is planar, and contiguous, and such geometry cannot cause extension to form a pull-apart basin, and in contrary such basins are typical features of step-overs and linkage fault geometries

20 (Fig. 2).

And typically horsetail splay faults curve from the main truck of the fault trace (Sylvester, 1988; Burg and Ford, 1997), and in a classic dextral strike-slip fault system such faults could be of certain restricted orientation with respect to the main fault (Figs. 2 and 3). The orientation of the major strike-slip fault of Kashmir basin is reported to be $\sim$ NW-SE (Alam et al., 2015), and the horsetail faults are shown to be of the same orientation as the major fault ( NW-SE), this is structurally impossible

25 (Fig. 3), and conflicts with the basin style of such faulting. Because with $\sim$ NW-SE strike of the major fault the horsetail splay structures will have either SW strike with a NW tectonic transport, or NE strike with a SE tectonic transport (Fig. 3c, d).

\subsection{Geologic and geomorphic evidence}

The bedrock geology of Kashmir basin shows Upper Carboniferous-Permian Panjal Volcanic Series and Triassic limestone are covered by Plio-Pleistocene fluvio-glacial sediments (Farooqi and Desai 1974). There is no evidence of a large scale 30 topographic, or lithology offset, which is typically associated with a major dextral strike-slip fault system. Shah (2013 b) 
Solid Earth Discuss., doi:10.5194/se-2016-4, 2016

Manuscript under review for journal Solid Earth

Published: 18 January 2016

(c) Author(s) 2016. CC-BY 3.0 License.

showed dextral offset of drainages on the SE of Kashmir basin, however, minor ( 20 to $\sim 40 \mathrm{~m}$ ) offset of these channels are related to the oblique convergence. And does not suggest or approve of a major dextral strike slip fault system.

The present geological, and structural architecture is consistent major $\sim$ NE dipping thrust faults (Fig. 1). The regional structural architecture is consistent with a piggy-back model, where Kashmir basin is riding on a number of thrust faults. And three (Fig.

5 4) SSW verging faults are presently considered active (e.g. Thakur, 2010; Shabir and Bhat 2012; Vasilios 2014; Shah, 2013, 2015), from south these are Main Frontal Thrust (MFT), Medlicott-Wadie Thrust (MWT), and Kashmir Basin Fault (KBF). And the current geomorphic, and structural setup of Kashmir basin is a product of the activity along these faults. It is impossible to create the present structural skeleton of Kashmir basin by a major dextral strike-slip fault, even if it has an oblique slip component (Figs. 3 and 4). This is because if a major dextral-slip is associated with a normal dip-slip component, which is

10 shown by the pull-apart model (Alam et al., 2015) then the overall topography, and geomorphology will suggest subsidence on hanging-wall portions, and relative uplift on foot-wall. This requires two scenarios; a) the major fault may either be dipping SSW or 2) NNE. The pull-apart model (Ahmad et al., 2015) shows topographic depression on the left side of the major fault (NNE side), which requires a NNE dipping fault with a normal faulting component (Fig. 3a). However, the entire Kashmir basin tilts $\sim$ NE (Fig. 1 and 3), and there is no evidence of normal faulting. There is no reported break or offset in topographic with an enormous amount of slip, which could be associated with a dextral-fault. Neither is there any evidence of a large scale strike-slip displacement of bedrock units (Burbank and Johnson, 1983).

\subsection{Geodetic evidence}

Shah (2013b) mapped the eastern extent of the KBF fault, and argued for a clear right-lateral strike-slip motion for a distance of $\sim 1 \mathrm{~km}$, which was shown by the deflection of young stream channels. The lateral offset varies from $\sim 20$ to $\sim 40 \mathrm{~m}$. This was

20 suggested to be a classical example of oblique convergence where thrusting is associated with a small component of dextral strike-slip motion. The recently acquired GPS data in Kashmir Himalaya (Schiffman et al., 2013a) confirms these observations, and suggests an oblique faulting pattern, wherein a range-normal convergence of $11 \pm 1 \mathrm{~mm} / \mathrm{y}$ is associated with a dextral-shear slip of $5 \pm 1 \mathrm{~mm} / \mathrm{y}$. They further suggest that obliquity is more towards the eastern portion of the valley. This clearly suggests that the resultant stress vector is oblique in Kashmir Himalaya, and thus the deformation is mainly absorbed by range-normal, and less so by shear components. A typical characteristic feature of oblique convergence.

\section{Discussion}

The Kashmir basin is suggested to have formed through a piggyback basin deformation style, however new studies (Alam et al., 2015, 2016) show it as a large pull-apart basin. The new model is structurally impossible, and conflicts with the geomorphology, geology, and tectonic setting of Kashmir basin. Thus, the possibility of having a major dextral-slip fault in

30 Kashmir basin is kinematically impossible, and it basically conflicts with the typical structural features that are possible in such an environment (Fig. 3). For example horsetail thrust structures do not run parallel with the trend of the main fault trace (Fig. 3), and it is kinematically impossible to have them on both the sides of a major fault tip (Fig. 3). It is equally impossible 
Solid Earth Discuss., doi:10.5194/se-2016-4, 2016

Manuscript under review for journal Solid Earth

Published: 18 January 2016

(c) Author(s) 2016. CC-BY 3.0 License.

to have the trace of a major strike-slip fault in the middle of a pull-apart basin (Fig. 2). Such a structural setting is inconsistent, and impossible. The structural architecture, and the evidence presented above suggests that Kashmir basin does not require a major strike-slip fault. And the conflicting structures that have been shown in pull-apart model are an indication that such a big-structure is not possible in Kashmir basin. Thus, the geological, and tectonic setting of Kashmir basin is largely consistent

5 with a piggy-back model (Burbank and Johnson, 1982). It does not support a large dextral fault, which is structurally impossible (see above), and contradicts with the basic geological, and structural set-up of Kashmir basin.

The location of the basin is north of the Main Frontal Thrust (MFT), the megathrust structure that accommodates $\sim 2 \mathrm{~cm} /$ year of a total of 4-5 cm/year of the regional convergence between the Indian and Eurasian plates (Schiffman et al., 2013; Vasilios 2014), and is considered actively growing (e.g. Bollinger et al., 2014; Malik et al., 2014; Kumahara \& Jayangondaperumal,

10 2013; Malik et al., 2010). And the surficial trace of the MFT has not been reported in Jammu and Kashmir, and thus it is assumed that it runs as a blind structure under Jammu (Vassallo et al., 2015) This fault is presently locked under the Kashmir region, and has the potential to host a major earthquake (Schiffman et al., 2013). There is another major active fault that runs under Raisi (Fig.1), which is also considered to host a major earthquake (Vassallo et al., 2015). The third major fault runs approximately through the middle of the Kashmir valley (Fig. 2b) and it can also host a major earthquake, very similar to the

15 Muzaferabad earthquake of 2005 (Shah, 2013a). The three active major faults that are mapped in Jammu and Kashmir are not well studied, and there are greater uncertainties in understanding whether the regional stress will be released on the frontal fault or on the interior faults. All these faults are $\sim \mathrm{SW}$ verging, and can be easily explained by the regional stress setup that a piggyback basin model portrays. However, pull-apart setting (Alam et al., 2015) requires the regional stress to be partitioned into normal, and shear components, which is not shown by seismicity, topography, and structural setting (see above).

20 Moreover the basic conceptual conditions for a major dextral strike-slip system are lacking (see above), thus, such a model is impossible in Kashmir basin.

\section{References}

Allen, R. V.: Automatic earthquake recognition and timing from single traces, B. Seismol. Soc. Am., 68, 1521-1532, 1978. 2113

25 Bean, C. J., De Barros, L., Lokmer, I., Métaxian, J.-P., O’ Brien, G., and Murphy, S.: Longperiod seismicity in the shallow volcanic edifice formed from slow-rupture earthquakes, Nat. Geosci., 7, 71-75, doi:10.1038/ngeo2027, 2013.

Ahmad, S., Bhat, M.I., Madden, C., Bali, B.S.: Geomorphic analysis reveals active tectonic deformation on the eastern flank of the Pirpanjal Range, Kashmir Valley, India, Arabian Journal of Geosciences., 7, 2225-2235, 2013, doi:10.1007/s12517013-0900-y.

30 Alam, A., Ahmad, S., Bhat, M. S., Ahmad, B.: Tectonic evolution of Kashmir basin in northwest Himalayas. Geomorph, 239, 114-126, 2015. 
Solid Earth Discuss., doi:10.5194/se-2016-4, 2016

Manuscript under review for journal Solid Earth

Published: 18 January 2016

(c) Author(s) 2016. CC-BY 3.0 License.

Alam, A., Ahmad, S., Bhat, M. S., Ahmad, B.: Response to the commentary by Shah, AA (2015) and further evidence supporting the dextral strike-slip pull-apart evolution of the Kashmir basin along the central Kashmir fault (CKF). Geomorph., $253,558-563,2016$.

Bhatt, D.K.: Stratigraphical status of Karewa Group of Kashmir, India: Himal. Geol., 6, 197-208, 1976.

5 Bollinger, L., Sapkota, S. N., Tapponnier, P., Klinger, Y., Rizza, M., Van der Woerd, J., Bes de Berc, S.: Estimating the return times of great Himalayan earthquakes in eastern Nepal: Evidence from the Patu and Bardibas strands of the Main Frontal Thrust, J. Geophys. Res.,119, 7123-7163, 2014.

Burbank, D.W., Johnson, G.D.: Intermontane-basin development in the past 4 Myr in the north-west Himalaya, Nature, 298, 432-436, 1982.

10 Burbank, D.W., Johnson, G.D.: The Late Cenozoic chronologic and stratigraphic development of the Kashmir intermontane basin, northwestern Himalaya, Palaeogeogr. Palaeoclimatol. Palaeoecol., 43, 205-235, 1983.

Burg, J.P., Ford,M.: Orogeny through time: an overview. Geol. Soc. Lond. Spec. Publ., 121, 1-17, 1997.

Farooqi, I.A., Desai, R.N.: Stratigraphy of Karewas, India, J. Geol. Surv. India., 15, 299-305, 1974.

Jaiswal, M.K., Bhat, M.I., Bali, B.S.: Luminescence characteristics of quartz and Feldspar from tectonically uplifted terraces

15 in Kashmir Basin, Jammu and Kashmir, India, Radiation Measurements, 44, 523-528, 2009.

Kumahara, Y., Jayangondaperumal, R.: Paleoseismic evidence of a surface rupture along the northwestern Himalayan Frontal Thrust (HFT), Geomorph., 180, 47-56, 2013.

Malik, J. N., Shah, A. A., Naik, S. P., Sahoo, S., Okumura, K., Patra, N. R.: Active fault study along foothill zone of Kumaun Sub-Himalaya: influence on landscape shaping and drainage evolution, Current Science, 106, $229,2014$.

20 Malik, J. N., Shah, A. A., Sahoo, A. K., Puhan, B., Banerjee, C., Shinde, D. P., Rath, S. K.: Active fault, fault growth and segment linkage along the Janauri anticline (frontal foreland fold), NW Himalaya, India: Tectonophysics, 483, 327-343, 2010. Mugnier, J.L., Gajurel, A., Huyghe, P., Jayangondaperumal, R., Jouanne, F., Upreti, B.: Structural interpretation of the great earthquakes of the last millennium in Central Himalaya, Earth Sci. Rev., 127, 30-47, 2013.

Schiffman, C.,Bikram Singh Bali., Walter Szeliga., Roger Bilham.: Seismic slip deficit in the Kashmir Himalaya from GPS 25 observations, Geophy. Res. Lett., 40, 5642-5645, 2013.

Shabir, A., Bhat, M.I.: Tectonic geomorphology of the Rambiara basin, SW Kashmir Valley reveals emergent = out-ofsequence active fault system, Himal. Geol., v. 33, p. 162-172, 2012.

Shah, A.A.: Earthquake geology of the Kashmir Basin and its implication for large earthquakes. Int. J. Earth. Sci, 102, 7, 19571966, 2013a.

30 Shah, A.A.: Tectonic geomorphology of the eastern extent of the Kashmir Basin Fault (KBF) zone. In: Grützner, C., Rudersdorf, A., Reicherter, K. (Eds.), 4th International INQUA Meeting on Paleoseismology, Active Tectonics and Archeoseismology (PATA), Oct 9-14 2013. Grützner \& Reicherter Geosolutions, Aachen, Germany, 2013 b.

Shah, A.A.: Kashmir Basin Fault and its tectonic significance in NW Himalaya, Jammu and Kashmir, India, Inte Int. J. Earth. Sci. 2015a 
Solid Earth Discuss., doi:10.5194/se-2016-4, 2016

Manuscript under review for journal Solid Earth

Published: 18 January 2016

(c) Author(s) 2016. CC-BY 3.0 License.

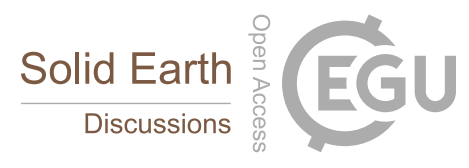

(c) (i)

Shah, A.A.: Alam Akhtar, Ahmad Shabir, Sultan Bhat, M., Ahmad Bashir, 2015. Tectonic evolution of Kashmir basin in northwest Himalayas, Comment, Geomorph., doi: 10.1016/j. geomorph. 2015.03. 025, 2015b.

Singh, I.B.: Sedimentation pattern in the Karewa basin, Kashmir Valley, India and its geological significance: J. Paleon. Soc. India, 27, 71-110, 1982.

5 Sylvester, A.G.: Strike-slip faults, Geol. Soc. Am. Bull. 100, 1666-1703, 1988.

Thakur, V.C., Jayangondaperumal, R., Malik, M.A., Redefining Medlicott-Wadia's main boundary fault from Jhelum to Yamuna, an active fault strand of the main boundary thrust in northwest Himalaya, Tectonophysics, 489, 29-42, 2010.

Vassallo, R., Mugnier, J.L., Vignon, V., Malik, M.A., Jayangondaperumal, R., Srivastava, P., Carcaillet, J., Distribution of the Late-Quaternary deformation in Northwestern Himalaya, Earth Planet. Sc. Lett., v. 411, p. 241-252, 2015.

10 
Solid Earth Discuss., doi:10.5194/se-2016-4, 2016

Manuscript under review for journal Solid Earth

Solid Earth

Published: 18 January 2016

Discussions

(c) Author(s) 2016. CC-BY 3.0 License.

(C) (1)

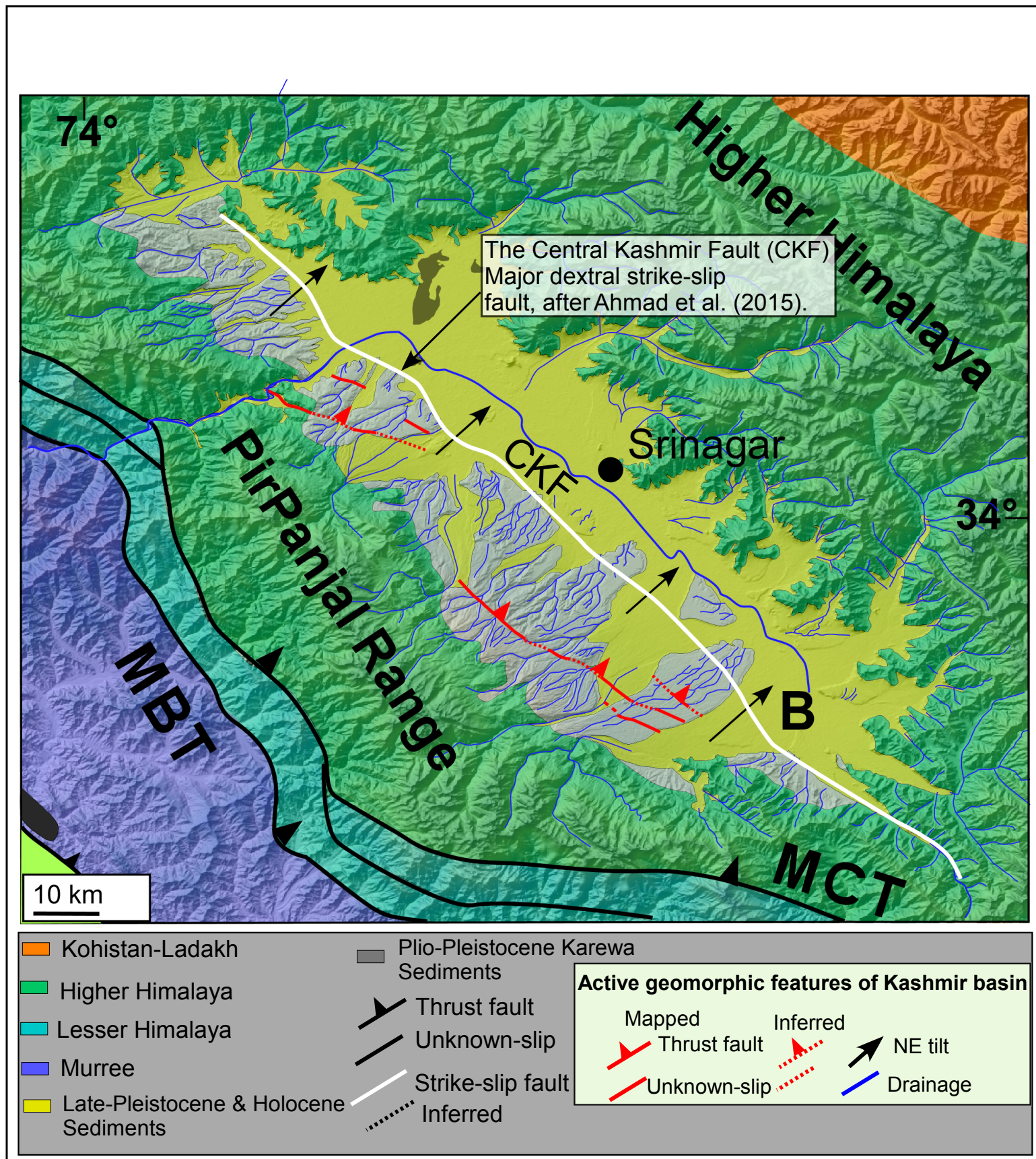

Figure 1. Simplified geology, and structural map of Kashmir basin, NW Himalaya (Modified from Thakur et al., 2010, and Shah, 2013a, 2015a), MCT=Main Central Thrust, MBT =Main Boundary Thrust. The Central Kashmir fault (CKF) of Ahmad et al. (2015) runs through the basin. 

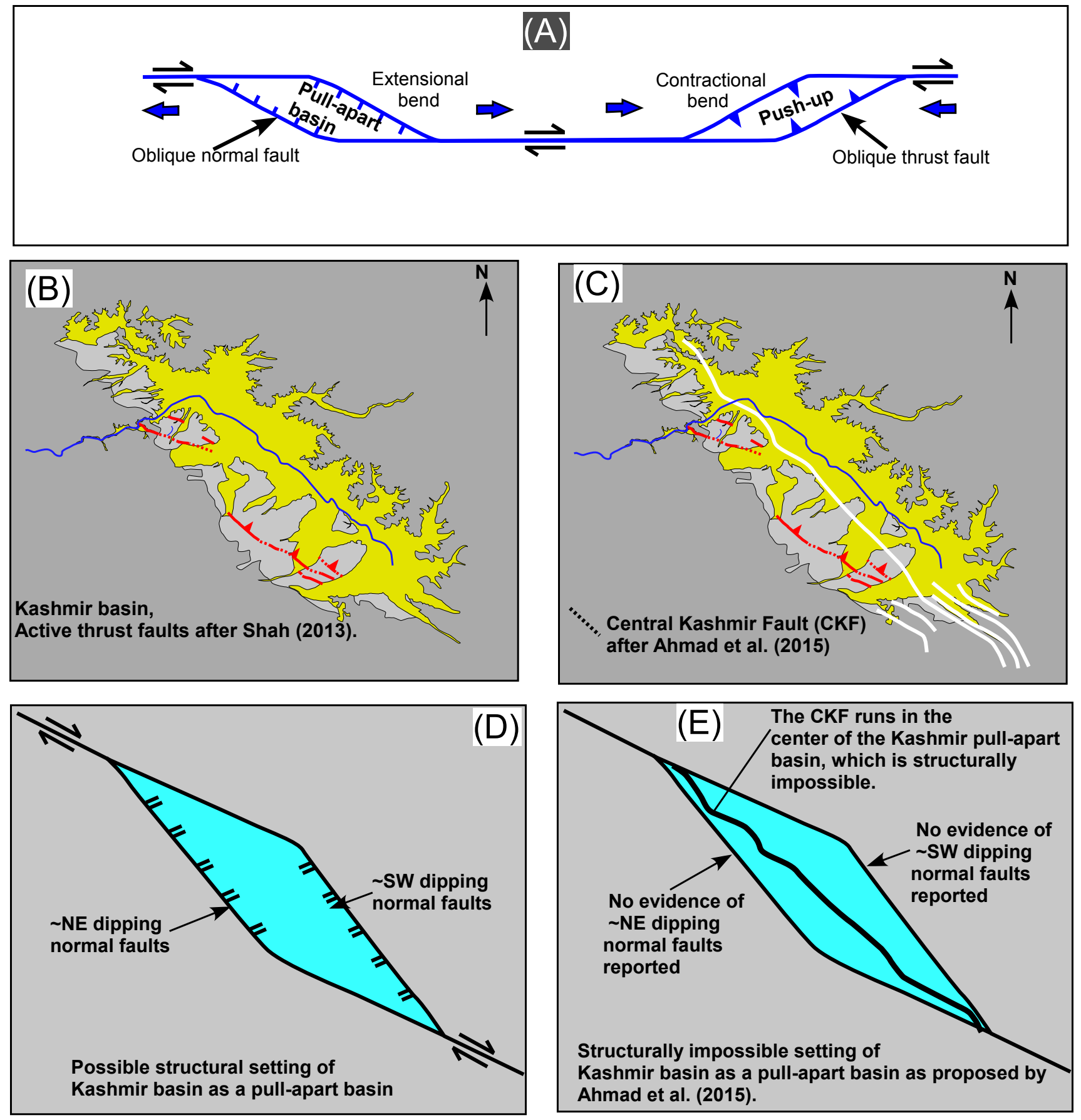

Figure 2. (a) Structures associated with a typical pull-apart basin setting. (b) Kashmir basin, and the mapped traces of active thrust faults (after Shah, 2013a). (c) Shows the mapped trace of Central Kashmir Fault (CKF), and the associated horsetail structures. (d) A typical example of a dextral strike-slip fault system, and a series of normal, oppositely verging, faults that accompany such a deformation pattern. (e) The mapped trace of CKF runs in the middle Kashmir basin, a proposed pull-apart basin, which is structurally impossible. 


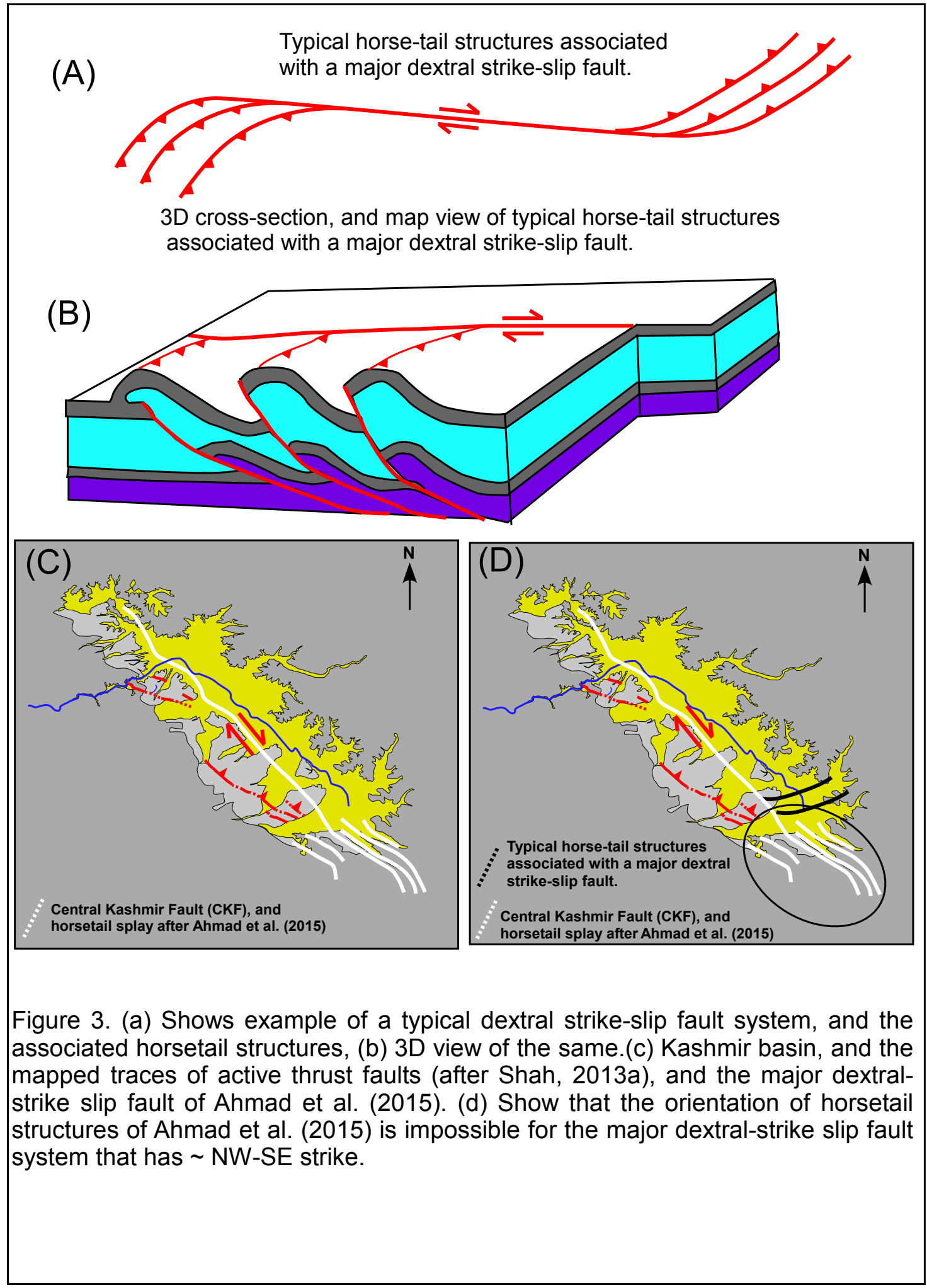




\section{(A)}
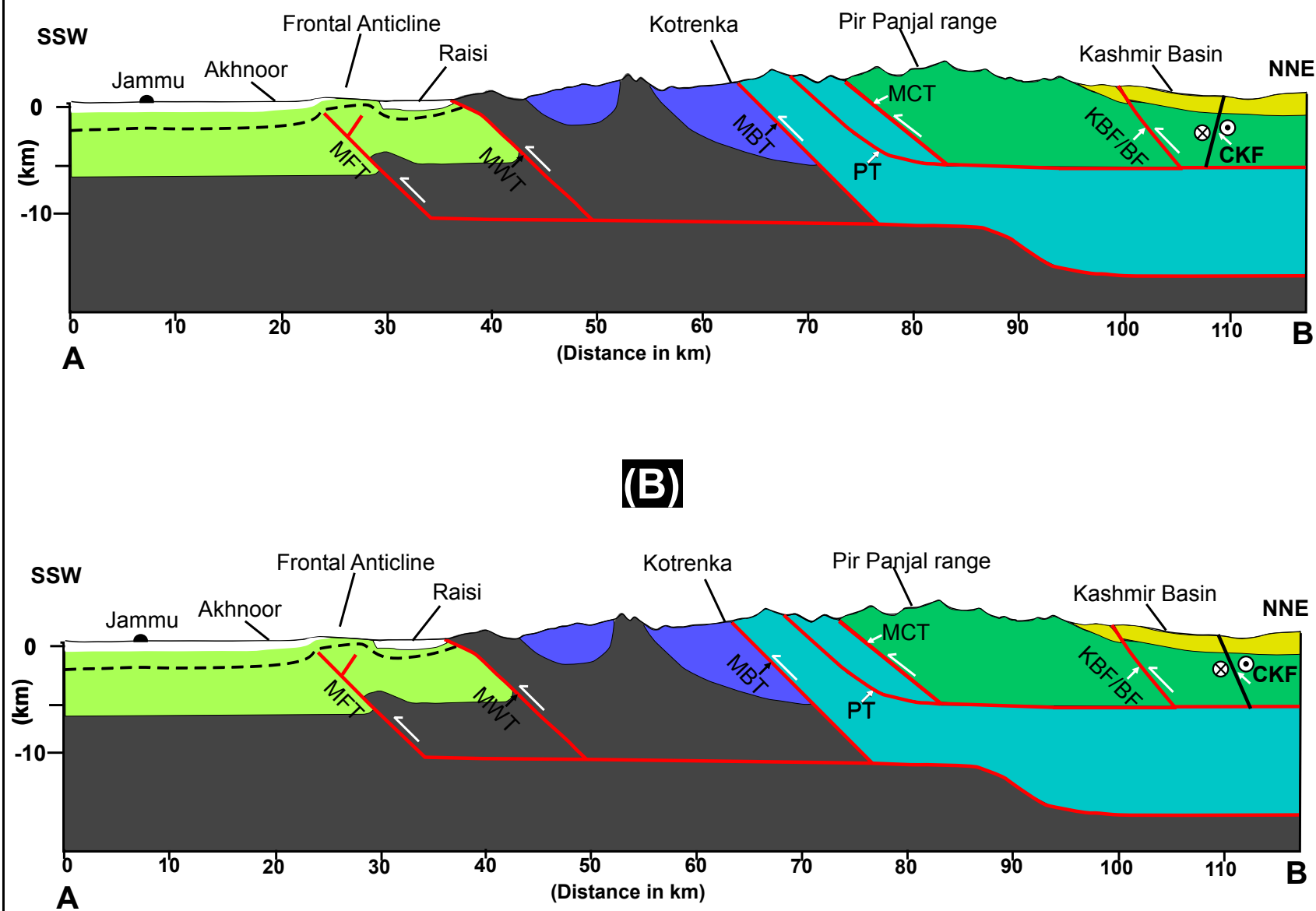

Figure $4 \mathrm{a}$ and $4 \mathrm{~b}$. Simplified geology cross sections of Jammu, and Kashmir region (after Vassallo et al. 2015 and Shah, 2015b). MCT=Main Central Thrust, MBT =Main Boundary Thrust, MWT= Medlicott-Wadia Thrust (MWT), and MFT =Main Frontal Thrust, KBF= Kashmir Basin Fault, BF= Balapur Fault, Panjal Thrust =PT, Central Kashmir Fault (CKF). 